\title{
RADIOEMISSION OF THE MODULATED ELECTRON BEAM INJECTED INTO IONOSPHERE ALONG THE GEOMAGNETIC FIELD
}

\author{
I.O.Anisimov ${ }^{1}$, O.I.Kelnyk ${ }^{1}$, Yang Yong ${ }^{1-2}$, Zhao Zheng Yu ${ }^{2}$ \\ ${ }^{1}$ Taras Shevchenko National University of Kyiv, Radio Physics Faculty, \\ 64 Volodymyrs'ka St., 01033, Kyiv, Ukraine, oles@univ.kiev.ua; \\ ${ }^{2}$ Wuhan University, School of Electrical and Information Science, \\ Luojia Hill, Wuhan 430072,China, luojiayang@vip.sina.com
}

Report contains calculation of the radioemission of semi-restricted thin modulated electron beam injected from the spacecraft board into the ionosphere plasma along the geomagnetic field. Radioemission appears due to the synchronism between the electric current wave of modulated beam and electromagnetic eigenmode of the anisotropic plasma. Radiation pattern for whistlers' frequencies is formed as a result of the interference between three independent modes with the same frequency and different wavelengths. Consequently, Pointing vector angular dependence is oscillatory at small angles. At larger angles, the radiation pattern has a sharp maximum near the resonant cone.

PACS: 52.35.Hr, 41.75.Fr

\section{INTRODUCTION}

Excitation of electromagnetic waves by the modulated electron beams injected into anisotropic plasma was observed many times both in space and laboratory experiments (see, e.g., [1-2]). One of the possible mechanisms of this phenomenon (for the simplest case when the beam is injected along the geomagnetic field) is transition radiation on the metal-plasma border [3]. This radiation was calculated in [4] for the laboratory experiments [2] where the transversal length of the transition radiation formation zone [5] was small relatively to the characteristic length of injector. The opposite case that is typical for ionosphere experiments is treated in this report. It corresponds to the radiation caused by the longitudinal restriction of the beam [6].

\section{MODEL DESCRIPTION AND BASIC EQUA- TIONS}

Cold plasma in the homogeneous constant magnetic field is treated. Cylindrical modulated electron beam injected in the plane $\mathrm{z}=0$ moves along the magnetic field. Alternative current density caused by the beam has a form

$$
\begin{aligned}
& \vec{j}(\vec{r}, t)=e_{z} j_{m} \alpha(r) \beta(z) \exp (i \omega t-i \chi z-z / L), \\
& \alpha(r)=\underset{\mathrm{O}}{\mathrm{M} l, r \mathrm{~J} a ;}, r \mathrm{i} a ; \quad \beta(z)=\underset{\mathrm{O}}{\mathrm{M}}, z, z \mathrm{i} 0 ; \\
& \mathrm{H} 0 .
\end{aligned}
$$

Here $r, \varphi, z$ are cylindrical coordinates, $\chi=\omega / \mathrm{v}_{0}, \mathrm{v}_{0}$ is the beam velocity, $L$ is the beam relaxation length, $\omega$ is the beam modulation frequency.

Inhomogeneous wave equation for vector-potential with the calibration condition $\varphi=0$ has a form:

$$
\operatorname{rot}(\operatorname{rot} \vec{A})-k_{0}^{2} \hat{\varepsilon} \vec{A}=\frac{4 \pi}{c} \vec{j}
$$

Here $\mathrm{k}_{0}=\omega / \mathrm{c}, \hat{\mathcal{\varepsilon}}$ is the dielectric permittivity tensor of cold anisotropic plasma that can be presented in the form

$$
\begin{aligned}
& \hat{\varepsilon}=\begin{array}{lll}
\breve{\varepsilon_{\perp}} & i \alpha & 0 \text { ч } \\
\mathrm{K}^{\mathrm{K}}-i \alpha & \varepsilon_{\perp} & 0_{\mathrm{b}}^{\mathrm{b}}
\end{array} \\
& \text { 片 } 0 \quad 0 \quad \varepsilon_{/ /} \text {B }
\end{aligned}
$$

$$
\varepsilon_{\perp}=1-\frac{\omega_{p}^{2}}{\omega^{2}-\omega_{H}^{2}}, \varepsilon_{/ /}=1-\frac{\omega_{p}^{2}}{\omega^{2}}, \alpha=\frac{\omega_{H} \omega_{p}^{2}}{\omega\left(\omega^{2}-\omega_{H}^{2}\right)},
$$

$\omega_{p}$ and $\omega_{H}$ are Langmuir and cyclotron frequencies, respectively.

Dispersion equation for electromagnetic waves in plasma corresponding to equation (2) without the right side can be presented as [7]

$$
\begin{gathered}
F=\varepsilon_{/ /} n_{z}^{4}-n_{z}^{2}\left[2 \varepsilon_{/ /} \varepsilon_{i}-n_{y}^{2}\left(\varepsilon_{/ /}+\varepsilon_{i}\right)\right]+ \\
+\left(\varepsilon_{/ /}-n_{y}^{2}\right)\left[\alpha^{2}+\varepsilon_{i}\left(n_{y}^{2}-\varepsilon_{i}\right)\right]=0, \\
n_{y}^{2}=k_{i}^{2} / k_{0}^{2}, \\
n_{z}^{2}=k_{/ /}^{2} / k_{0}^{2} .
\end{gathered}
$$

\section{CALCULATION OF THE RADIATION FIELD}

It is suitable to present the vector-potential components and current density in the form of Fourrier integral over $\mathrm{z}$ and Hankel integral over $\mathrm{r}$ :

$$
\begin{aligned}
j_{z}(r, z) & =\int_{0}^{\infty} J_{0}\left(k_{i} r\right) k_{i} d k_{i} \int_{-\infty}^{\infty} \exp \left(i k_{/ /} z\right) j_{z}\left(k_{i}, k_{/ /}\right) d k_{/ /} \\
A_{z}(r, z) & =\int_{0}^{\infty} J_{0}\left(k_{i} r\right) k_{i} d k_{i} \int_{-\infty}^{\infty} \exp \left(i k_{/ /} z\right) A_{z}\left(k_{i}, k_{/ /}\right) d k_{/ /}
\end{aligned}
$$

$$
A_{r, \varphi}(r, z)=\int_{0}^{\infty} J_{1}\left(k_{i} r\right) k_{i} d k_{i} \int_{-\infty}^{\infty} \exp \left(i k_{/ /} z\right) A_{r, \varphi}\left(k_{i}, k_{/ /}\right) d k_{/ /}
$$

Substituting (4)-(5) into (2), one can obtain the components of vector-potential spectrum from algebraic equations. Denominators of these expressions contain the dispersion function (3). Consequently the singular points of the integrands in (5) correspond to the Cherenkov resonance conditions i.e. synchronism between the partial cur- 
rent waves caused by the modulated electron beam and electromagnetic eigenmodes of anisotropic plasma.

Integrals (5) can be calculated using resides' method for integration over $k_{\|}$and stationary phase method for integration over $k_{\perp}$ (in the far radiation zone, $\mathrm{k}_{0} \mathrm{R}>>1$ ). For the whistlers' frequency range the results can be presented in the form:

$$
\begin{aligned}
& A_{r}(R, \theta)=-i I_{m} \text { r } \\
& \mathrm{e}_{j} \frac{J_{1}\left(k_{0} a n_{2} \sin \Theta\right) n_{z 2}\left(n_{z 2}^{2}+\left(n_{2} \sin \Theta\right)^{2}-\varepsilon_{\perp}\right)\left(n_{2} \sin \Theta\right)^{3 / 2}}{k_{0}^{2} a R \sqrt{\sin \theta}\left[\left(k_{0} n_{z 2}+\chi\right)+i L^{-1}\right]\left(n_{z 2}^{2}-n_{z 4}^{2}\right)} \\
& \underset{3}{\frac{3}{d} d n_{2}} \sin \Theta+n_{2} \cos \Theta \Psi_{\Theta_{j}}^{4}\left(| S _ { + j } ^ { \prime \prime } ( \Theta _ { j } ) | ^ { - 1 / 2 } \operatorname { e x p } \left\{i k_{0} R S_{+j}\left(\Theta_{j}\right)-\right.\right.
\end{aligned}
$$

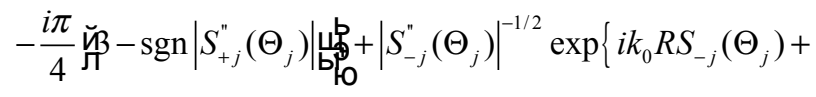

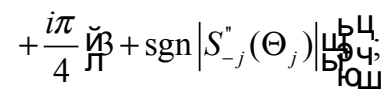

$$
\begin{aligned}
& A_{\phi}(R, \theta)=e_{j} \frac{2 I_{m} J_{1}\left(k_{0} a n_{2} \sin \Theta\right) n_{z 2}\left(n_{2} \sin \Theta\right)^{3 / 2}}{\left[\left(k_{0} n_{z 2}+\chi\right)+i L^{-1}\right] k_{0}^{2} a R\left(n_{z 2}^{2}-n_{z 4}^{2}\right)} \text { ґ }
\end{aligned}
$$

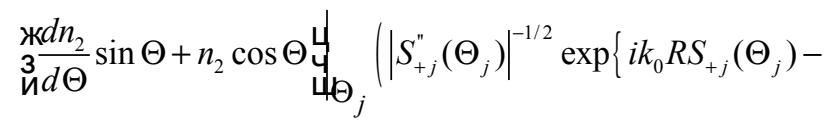

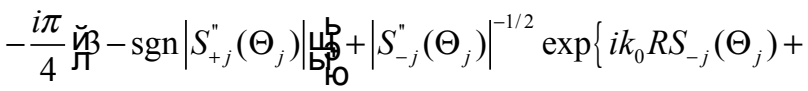

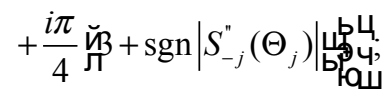

$$
\begin{aligned}
& A_{z}(R, \theta)=-I_{m} \text { Ґ } \\
& \mathrm{e}_{j} \frac{J_{1}\left(k_{0} a n_{2} \sin \Theta\right) \breve{y}\left(n_{z 2}^{2}-\varepsilon_{\perp}\right)\left(n_{z 2}^{2}+\left(n_{2} \sin \Theta\right)^{2}-\varepsilon_{\perp}\right)+\alpha \text { 㟧 }}{a k_{0} n_{y}\left[\left(k_{0} n_{z 2}+\chi\right)+i L^{-1}\right] k_{0} R \sqrt{\sin \theta} n_{z 2}\left(n_{z 2}^{2}-n_{z 4}^{2}\right)}
\end{aligned}
$$

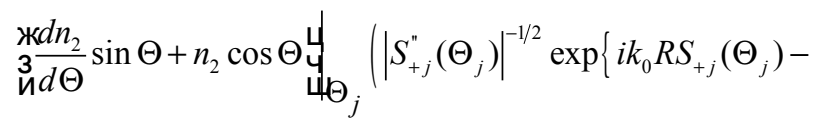

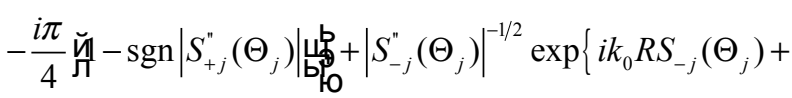

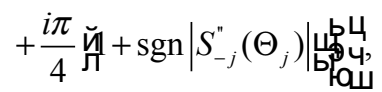

$$
\begin{aligned}
& S_{ \pm j}= \pm n_{2}\left(\Theta_{j}\right) \cos \left(\Theta_{j} \mp \theta\right) \text {. }
\end{aligned}
$$

Here $\mathrm{n}_{2,4}$ are the roots of dispersion equation (3) with the positive real part, $\theta$ is the axial angle of the view point direction, $\Theta \mathrm{j}$ is the stationary phase point where

$$
\frac{d S_{ \pm j}}{d \Theta}=0 .
$$

Summa in (6) is calculated upon all the stationary phase points. In general, there are 3 such points both for forward and backward radioemission. These points correspond to the independent modes with different wave numbers that interfere during their propagation. So the radiation at each angle consists of three interfering components.
Finally, one can obtain the expression for radial component of the Pointing vector (in the spherical coordinates $\mathrm{R}, \theta, \phi)$ :

$$
\begin{aligned}
\mathrm{X}_{R}= & \frac{i \omega c}{4 \pi}\left[A_{\theta}^{*} \operatorname{rot}\left(A_{\varphi}\right)+A_{\varphi}^{*} \operatorname{rot}\left(A_{\theta}\right)\right]= \\
& =\frac{i \omega c}{4 \pi}\left[A_{\theta}^{*}\left(\frac{\partial\left(A_{\theta} R\right)}{\partial R}-\frac{\partial A_{R}}{\partial \theta}\right)+A_{\varphi}^{*} \frac{1}{R} \frac{\partial}{\partial R}\left(R A_{\varphi}\right)\right]
\end{aligned}
$$

\section{RADIATION PATTERN AND TOTAL RADI- ATED POWER}

Pointing vector was calculated numerically for the parameters typical for ionosphere $\left(\omega=2 \cdot 10^{6} \mathrm{~s}^{-1}\right.$, $\left.\omega_{H}=7 \cdot 10^{6} \mathrm{~s}^{-1}, \omega_{p}=6 \cdot 10^{7} \mathrm{~s}^{-1}\right)$ when frequencies fall into the whistler band $\left(\omega_{p}>>\omega_{H}>>\omega\right)$. At these conditions all the three modes corresponding to the stationary phase points are present at small angles. Fig. 1 shows the angular dependence of the Pointing vector for this case. Interference between the three modes with different wave numbers causes to the oscillatory radiation pattern at these small angles.

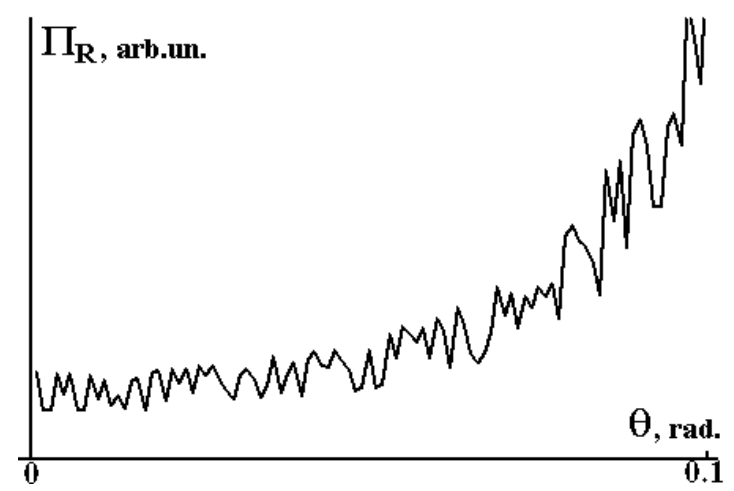

Fig. 1. Pointing vector angular dependence at small angles $\left(v_{0}=5.5 \cdot 10^{6} \mathrm{~m} / \mathrm{s}, \omega=2 \cdot 10^{6} \mathrm{~s}^{-1}, \omega_{H}=7 \cdot 10^{6} \mathrm{~s}^{-1}, \omega_{p}=6 \cdot 10^{7} \mathrm{~s}\right.$ 1)

For the angles larger than some critical value, two of the stationary phase points vanish and the directivity diagram is formed only by one mode. As the result, the angular dependence of the Pointing vector monotonically increases with the angle. Fig. 2 shows the Pointing vector angular dependence for wide band of angles.

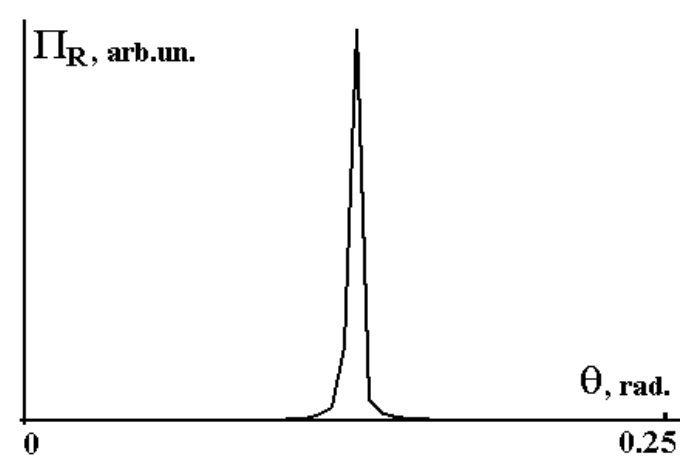

Fig. 2. Pointing vector angular dependence for wider angle band $\left(v_{0}=5.5 \cdot 10^{6} \mathrm{~m} / \mathrm{s}, \omega=2 \cdot 10^{6} \mathrm{~s}^{-1}, \omega_{H}=7 \cdot 10^{6} \mathrm{~s}^{-1}\right.$, $\left.\omega_{p}=6 \cdot 10^{7} \mathrm{~s}^{-1}\right)$ 
One can see that the radiation efficiency greatly increases near the angle of the resonant cone so the radiation at smaller angles shown at Fig. 1 becomes negligible. Radioemission at even larger angles falls into the resonant cone and vanishes.

If the Cherenkov resonance condition for the beam modulation wave number $\chi$ is satisfied, the radiation forward exceeds substantially the radiation backward. In the opposite case the forward and backward radiated powers are approximately equal.

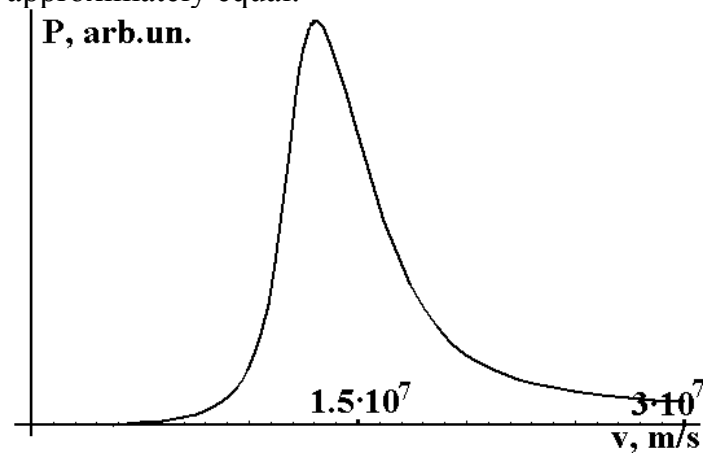

Fig.3. Total radiated power against the beam velocity $\left(\omega=2 \cdot 10^{6} \mathrm{~s}^{-1}, \omega_{H}=7 \cdot 10^{6} \mathrm{~s}^{-1}, \omega_{p}=6 \cdot 10^{7} \mathrm{~s}^{-1}\right)$

Numerical calculation shows that total radiated power grows proportionally to the square of $\mathrm{v}_{0}$ for small beam velocities (see Fig.3). One can see the optimal radiation conditions at some velocity and radiated power greatly increases near that value. For the simulation parameters, efficiency of the radiation at maximum is about $10^{-3}$. For high beam velocities, total radiated power decreases. This effect is a result of the violation of the Cherenkov resonance condition between the beam and whistler modes.
The character of the angular dependence of the energy flow is similar to the results obtained in [4].

This work was partially sponsored by the China Scholarship Council (CSC).

\section{REFERENCES}

1. Artificial particle beams in space plasma studies./ Ed. B.Grandal. NY, London: "Plenum Press", 1984.

2. M.Starodubtsev, C.Krafft, P.Thevenet, A.Kostrov. Whistler wave emission by a modulated electron beam through transition radiation. // Physics of Plasmas(6), 1999, \# 5, p. 1427-1434.

3. I.O.Anisimov, O.I.Kelnyk. On the possibility of observation of whistler transition radiation in active beam-plasma experiments in the ionosphere.// Kyiv University Bulletin. Physics and Mathematics. 1998, Issue 4, p. 238-242. (In Ukrainian).

4. I.O.Anisimov, O.I.Kelnyk, C.Krafft, T.V.Nychyporuk. Whistler Wave Emission by a Modulated Electron Beam on a Metal-Plasma Boundary. // Problems of Atomic Science and Technology. Ser:Plasma Electronics and New Acceleration Methods (3). 2003. \#4, p.74-77.

5. I.O.Anisimov, O.I.Kelnyk. On the transversal length of the transition radiation formation zone in the magnetoactive plasma. // Kyiv University Bulletin. Radio Physics and Electronics. 2001, Issue 3, p. 5 - 9. (In Ukrainian).

6. A.I.Rogashkova. Waves excitation in the isotropic inhomogeneous plasma by the modulated electron beam. // Radio Technics and Electronics (25). 1980. \#5. p.1042-1050. (In Russian).

7. V.L.Ginsburg. Electromagnetic waves propagation in plasmas. Moscow: "Nauka”, 1967. (In Russian).

\title{
ИЗЛУЧЕНИЕ МОДУЛИРОВАННОГО ЭЛЕКТРОННОГО ПУЧКА, ИНЖЕКТИРУЕ- МОГО В ИОНОСФЕРУ ВДОЛЬ ГЕОМАГНИТНОГО ПОЛЯ
}

\author{
Ян Юн, И.А. Анисимов, А.И. Кельник, Жао Жень Ю
}

Доклад содержит расчет излучения тонкого полуограниченного модулированного электронного пучка, инжектируемого с борта космического аппарата в ионосферную плазму вдоль направления геомагнитного поля. Радиоизлучение возникает вследствие синхронизма между парциальной волной тока модулированного электронного пучка и собственной электромагнитной волной анизотропной плазмы. Диаграмма направленности для свистового диапазона формируется в результате интерференции между тремя модами с одинаковой частотой, но разными длинами волн. Соответственно, угловая зависимость вектора Пойнтинга является осциллирующей для малых углов. Для больших значений углов диаграмма направленности имеет резкий максимум вблизи резонансного конуса.

\section{ВИПРОМІНЮВАННЯ МОДУЛЬОВАНОГО ЕЛЕКТРОННОГО ПУЧКА, ІНЖЕ- КТОВАНОГО В ІОНОСФЕРУ ВЗДОВЖ ГЕОМАГНІТНОГО ПОЛЯ}

\author{
Ян Юн, І.О. Анісімов, О.І. Кельник, Жао Жень Ю
}

Доповідь містить розрахунок випромінювання тонкого напівобмеженого модульованого електронного пучка, інжектованого з борту космічного апарату в іоносферну плазму вздовж напрямку геомагнітного поля. Радіовипромінювання виникає внаслідок синхронізму між парціальною хвилею струму модульованого електронного пучка і власною електромагнітною хвилею анізотропної плазми. Діаграма спрямованості для свистового 
діапазону формується в результаті інтерференції між трьома модами з однаковою частотою, але відмінними довжинами хвиль. Відповідно кутова залежність вектора Пойнтінга для малих кутів виявляється осцилюючою функцією. Для більших кутів діаграма спрямованості має різкий максимум поблизу резонансного конусу. 